\title{
A STUDY OF THE EFFICACY OF SERVICE LEARNING ON STUDENTS' LEARNING OUTCOME
}

\section{LI-CHU CHEN}

\begin{abstract}
:
The main purpose of the study is to explore how service learning involvement affects students' learning outcome. Subjects were students who took the course of English Teaching for Children for 1 year and were required to take at least one module test of TKT (Teaching Knowledge Test). The results indicate that those who participated in service-learning programs and fulfilled one or more service hours had better performance on the test. 46 students took the test of Module 1, and 40 of them have been involved in service-learning program, with $42 \%$ reaching band 3 and $58 \%$ reaching band 2 . In addition, attendance and participation in group work, discussion and personal reflection are also taken into account to evaluate students' performance. The results shows that not only do students who devoted time to service learning get acquainted with teaching process but they also obtain hands-on experience and show positive career development. It is concluded that service learning helps contribute to students' positive attitudinal outcome and better preparation for tests and that service learning integrated into teaching course is increasingly important.
\end{abstract}

\section{Keywords:}

service-learning; service-learning program; learning outcome

JEL Classification: A00

\section{Authors:}

LI-CHU CHEN, Shu Zen Junior College of Medicine and Management, Taiwan, Email: sinead2147@ms.szmc.edu.tw

\section{Citation:}

LI-CHU CHEN (2016). A Study of the Efficacy of Service Learning on Students' Learning Outcome. International Journal of Teaching and Education, Vol. IV(4), pp. 1-11., 10.20472/TE.2016.4.4.001 


\section{Introduction}

Service-learning has been recognized as a form of experiential education in which students engage in activities which are designed to promote students' learning and selfdevelopment (Jacoby, 1996). However, compared to the United States, the concept of integrating service-learning with education is still in its beginning stage. The combination of community service with school curricula has spread in schools and colleges campus in Taiwan since late 1990s. As a new pedagogy to promote education by implementing service-learning (Ministry of Education, 2008), some universities and colleges have started to combine service-learning with academic course (Feng, 2003). Therefore, to evaluate students' learning outcome, the study attempts to demonstrate the concept of the integration of knowledge and skills with practical experience and the support for service-learning implementation in academic course.

\section{Literature Review}

The original concept of experiential learning and reflection can be referred to John Dewey's theory (1938). Dewey noted that genuine education comes after meaningful and situational experience. In the 1930s and 1940s, Dewey and Tyler stated that how students benefit a great deal from when they are involved in their own learning. In Jacoby's (1996) perspective, service-learning is viewed as a form of experiential education engaging students in activities that address community needs together with opportunities intentionally created for students to improve their learning and promote self-development. Forman and Wilkinson (1997) referred to service-learning as a pedagogy that enhanced the development of skills and knowledge required for further participation in educational or career life. Bringle \& Hatcher (1995) defined service learning as:

a course-based, credit-learning educational experience in which students participate in an organized service activity that meets identified community needs and reflect on the service activity is such a way as to gain further understanding of course context, a broader appreciation of the discipline, and enhanced sense of civic responsibility.

In addition, Signmon (1979) and Rosengerg (2000) proposed that service-learning combining service work with academic learning through structured opportunities and active reflection empowers students' responsibility and learning enthusiasm. Based on the concept that service-learning is an integral part of education, many studies support the efficacy of service-learning in producing desirable student learning outcomes (Reising, Allen, \& Hall, 2006). Also, researches have indicated that service-learning benefits students in many ways including personal and interpersonal development, 
social accountability, and self-improvements in academic learning (Eyler, Giles, Stenson, \& Gray, 2001).

\subsection{Service-learning in teacher education}

Service-learning has received increased recognition as an essential and integral component of teacher education program. Related studies (Erickson \& Anderson, 1997; LaMaster, 2001) have proved that field-based experience can improve students' attitudes toward teaching and foster teacher preparation education. By participating in service-learning curriculum in teacher preparation program, students can more identify themselves with teacher methods class. In addition, critical self-reflection in teaching has been regarded as an effective way to assess students' self-growth and selfdiscovery in preparing themselves for better teachers (Rrancis, 1995; Zeichner, 1981; Zeichner \& Teitlebaum, 1982). According to the literature review mentioned above, we can find that service-learning is beneficial to students' learning outcomes in teacher preparation education and self-development in being a teacher. The concept of servicelearning in promoting students' learning towards being teachers facilitates the work on this study.

\subsection{Purpose of the study}

The purpose of the study is to examine the effectiveness of service-learning in TKT (Teaching Knowledge Test) course, aiming to prepare students for being children English teachers, by measuring students learning outcomes of taking TKT exam. To further assess students' learning result, the study also examines the following research questions:

RQ1: What other benefits do students perceive after participating in service-learning curriculum?

RQ2: How does service-learning affect students' perception of being a children English teacher?

\section{Methodology}

The main focus of the study is to investigate how service-learning influences students' learning outcomes of taking TKT exams. Qualitative study was designed for this study in order to explore more of students' perceptions and experiences of being children English teachers by participating in service-learning curriculum.

\subsection{Setting and participants}

The participants were 47 English major students in their third year of 5-year college education. The courses for children English teaching are designed for 2 hours per week 
for 2 semesters. Those who enroll in these courses are recommended to take part in service-learning curriculum in the local elementary school and are required to take at least one module test of TKT (Teaching Knowledge Test) as a prerequisite of the completion of the courses.

In order to prepare students for TKT test, the courses include 3 different modules, which are Module 1 (Language and background to language learning and teaching), Module 2 (Lesson planning and use of resources for language teaching) and Module 3 (Managing the teaching and learning process). At the time when courses were carried out, students enrolled in the $1^{\text {st }}$ semester were divided into groups to be arranged to observe English teachers' lessons at the local school where the service-learning would take place in the $2^{\text {nd }}$ semester. Students not only observed the lesson performed by the English teachers but would have an after- class discussion with the teachers for details from lesson plan to class management. Given the number of students, the 8-week long curriculum only allowed each group to have one opportunity for class observation. In the $2^{\text {nd }}$ semester, considering personal interest and concerns, approximately 40 students voluntarily took part in the service-learning curriculum. Starting from the second week, each group consisting of 2-3 voluntary student teachers was allowed to carry out independent teaching in the assigned classes 2 to 3 times throughout the semester. The 15-week long service-learning curriculum was intended to engage students in actual teaching practice where they could take up the role and responsibility of being teachers. Teaching performances were assessed by college supervisor and instructor who were responsible for the courses of children English teaching. Also, student teachers were required to write their own reflection during their teaching practice, demonstrating how they perceived and experience teaching activities, how they applied what they've learned from classes to real teaching, and the weakness and strengths they thought to be a children English teachers.

\subsection{Data collection and analysis}

In order to relate the service-learning curriculum to students' learning outcome on TKT test, qualitative study were used to obtain the answers to the research questions presented above. Each student's notes from observing lessons and personal reflection were analyzed and categorized to present the correlation between the result of TKT test and student's learning and teaching experience. Emerging categories were developed after reading the data and color highlighting key words, sentences or passages that were coherently written. The analysis of the data served to illustrate key perceptions and experiences of the student teachers' teaching practice and their performance on TKT test. 


\section{Results}

Analysis of the data collected from students' class observation and reflection reveals some positive findings related to student teachers' own development in many positive ways, which are consistent with the research questions presented. To extract the connection between learning outcome and students' perception and experience of service-learning outcome, the analysis is based on the following categories to identify students' learning. Student learning from:

(1) Class observation;

(2) Practical teaching experience

Each is examined in more detail.

(1) Students learning from class observation

Before students were provided with the opportunity to observe real teaching conducted by the English teacher in local elementary school, they were acquainted with the teaching knowledge through the course of English Teaching for Children. Without practical teaching experience, students needed to involve themselves in real teaching environment to help them concrete the concept of teaching English. Therefore, the majority of students found the class observation very helpful:

Before the class, the teacher had to spend her spare time referring to teaching references to create fun activities so that students were interested in the unit being taught. Also, the teacher had to stick to the timing of each procedure of the lesson in order not to delay the subsequent lessons. (Jennifer)

It was evident that the class observation had a very positive influence on the student's general understanding of what teaching English was about. Through the observation, the student was aware of the importance of prior preparation for the lesson and time management, both of which played important roles in a teaching activity. The observation experience helped the student realize the abstract concept of a lesson plan. Aside from this, some data indicated that being a teacher had to be creative and innovative, which in turn motivate student teachers to adopt new teaching methods:

In the class, the teacher took advantage of media technology to help students to learn. Students were asked to watch a video and then were given a learning sheet, on which they had to answer the questions regarding the video. The video teaching method not only raised students' attention but motivated students to learn. (Ting) 
Through the observation, the student came to realize that it was important to create or adopt different teaching activity to help students pay attention to what they were learning. With the post-lesson discussion, Ting also pointed out that thought there were teaching manual accompanying the textbook, the teacher had to come up with various teaching activities to meet students' need for learning. In addition, through the observation, students also perceived some difficulties and possible solutions in the real teaching situation:

In the class, some of the students were not listening to the teacher, and therefore the teacher would punish them by deducting their points for winning a prize instead of yelling or shouting at them. Due to the limited time for the lesson, the teacher had to treat those kids with patience and care, which made me strongly believe that having rich teaching experience was the key to being a successful teacher. (Aaron)

Most students thought of being an English teacher for children as very difficult, partly because they didn't know how to get along with the kids and partly because they didn't know how to deal with the difficulties coming from the teaching activity. Through the class observation, students had the opportunity to observe teachers handling the difficulties they might encounter in their own teaching, which helped lessen their worries and boost their confidence when they delivered their lessons.

I learned a lot from the teacher in a post-class discussion with the teacher who not only showed us how to make good use of the teaching resources on the Internet but teach us how to solve the problems emerging from the teaching. (Sunny)

It was obvious that students benefited greatly from opportunities to observe a class and the post-class discussion with the teachers proved to be particularly helpful for those who would experience difficulties in delivering lesson contents, engaging students in learning activities and preparing for a lesson.

(2) Students learning from practical teaching experience

To apply what student teachers learned from the teaching course and class observation to real teaching, they were engaged in the service-learning practice in the local elementary school. When they started their own teaching, they would consult the instructor for advice on the lesson plan as well as solutions to the problems they would encounter. When these student teachers delivered their lesson to local elementary students, most of them show positive learning attitude toward the course: 
It was great that I could actually apply what I learned in class to the real teaching situation. Before I taught, I had to discuss the lesson plan with my instructor to make sure that the timing of each stage of the teaching was appropriate and feasible, for managing time well was important when delivering a lesson. (Vivian)

When student teachers were provided with the opportunity to apply what they learned from the course to their own teaching activity, they came to realize the key elements in planning a lesson. To most students who took the TKT course didn't seem to comprehend what the course taught them. Through the service-learning, student teachers could turn the abstract concept of teaching into concrete teaching activity. During the personalized process, student teachers were able to step into the next stage of what service-learning directed them:

At first, I thought teaching English for children was difficult and I was afraid that I couldn't be a good teacher. With the experience of class observation and practical teaching, I learned a lot and had a different look on being an English teacher. Most importantly, I could improve myself by teaching English for children. (Wendy)

In Wendy's case, she was motivated and encouraged by the teaching experience. Besides, she also showed a positive attitude toward being an English teacher, believing that she could improve herself in teaching skills and career development. Through service-learning, most student teachers felt they were under pressure, for they had to spend time for the lesson plan and rehearsal before they actually delivered their own lesson, which motivated them to learn more:

When I was preparing for the lesson, I had to refer to a variety of resources to help students to learn. While looking for the suitable and appropriate activity for my own teaching, I learned how to organize my teaching ideas and put them into action. What's more, I found it important and necessary to learn new things so that I could always have new ideas for teaching. (Chen)

At first, it was difficult to teach these elementary school students due to their different English level. Also, because of their short attention span, my group had to spend time talking about the games and activities to be incorporated into the lesson plan so that we can help these students to learn English in a fun way. (Winnie)

With practical teaching experience, student teachers came to know the importance of make sufficient preparation for a lesson plan and available teaching resources. Most 
importantly, autonomous learning played an essential part in being a teacher. To make a lesson interesting and engage students in the learning activity, a teacher had to be creative and innovative in order to motivate students to learn. Some student teachers even indicated that their interaction with the students encouraged them to be English teachers:

When I became familiar with the students, I felt more confident in terms of teaching. And I gained a great sense of achievement when students did well in class and asked me questions, which really increased my enthusiasm to be an English teacher. ( $\mathrm{NaNa})$

I felt a great sense of accomplishment when I helped the elementary school students learn more and when they felt confident in speaking English. Seeing them making progress in learning English, I was inspired and encouraged to be an English teacher so that I can learn more and teach more. (Nancy)

When students knew how to address the difficulties they experienced in delivering a lesson, they would then gain a sense of achievement in teaching due to the fact that they could manage the class better and knew how to get along with young kids, which in turn would facilitate their teaching activities. With the positive learning outcome, there was no doubt that student teachers benefited a lot from their own teaching experience and considered being an English teacher a good career choice and self-improvement.

\section{Discussion}

In this study, 47 English-major students took part in the class observation in the $1^{\text {st }}$ semester and 40 students undertook a 15-week long service-learning curriculum in the local elementary school. The study demonstrated rich interactions between student teachers and elementary school students. The relationship between student teachers couldn't be made light of. From the analysis of the data collected, student teachers displayed many positive thoughts and valuable experience, assisting them in transferring the role of students to that of beginning teachers.

The findings of the study are strongly consistent with the learning outcomes proposed at the beginning of the study. Wenger (1998) claimed that learning is fundamentally experiential. In the personal reflection, students tended to describe their perceptions of the service-learning as a personal growth and experience, guiding them to further explore their own potential in teaching. In other words, the process of learning to teach was a key to assisting these student teachers with better comprehension of what they learned from the course and what they were doing in service-learning activity, which is accordance with Dewey's claim, learning by doing. Through the engagement in activities, student teachers' sharing difficulties and problems with fellow student teachers and 
instructors also revealed that they were able to address the problems arising from their teaching activity and attain success by interacting with elementary school students, from whom they obtained positive feedback and encouragement. These experiences not only led those student teachers to gain the sense of achievement but also attributed to their personal growth in a meaningful way.

After taking the academic course and engaging in service-learning curriculum, students were required to take at least one module test of TKT (Teaching Knowledge Test). In this study, 46 students took the test of Module 1, and 40 of them have been involved in service-learning program, with $42 \%$ reaching band 3 and $58 \%$ reaching band 2 . The test result revealed that those who were involved in the service-learning activity had better performance on the test. Among the students who took the module test and participated in service learning, 17 out of 40 students reached band 3 on the rubrics of 4 different levels starting from band 1 to 4 . Based on the service hours recorded, these 17 students filled more hours than those reaching band 2 on the module test. Some of them even had participated in other camps related to English teaching and activities. The test result suggested that engagement in teaching practice contributed to students' acquisition of professional knowledge of an academic course. Motivated by the teaching experience and test results, many of the students showed eagerness to take more module tests to equip themselves with exquisite knowledge and qualifications needed to be and English teacher for children, though the study didn't allude to the results on other module tests. There is no doubt that to elicit satisfactory learning outcomes, students should have further participation in service learning practice associated their academic course.

\section{Conclusions and implications}

The study is situated in the context of class observations and 15-week-long servicelearning curriculum, aiming to provide student teachers with the opportunities to carry out their own learning-to-teach practice in the school environment and to find out the correlation between students' participation in service learning practice and learning outcomes, which serves a way to understand students' points of view about what they learn and how they apply it to their own teaching activity through the process of assuming the part of teachers. In this study, the findings suggest that service-learning practice does help students gain better understanding of the course materials and teaching preparation, which in turn facilitates their application to their own teaching and test-taking. The study report also challenges the concept of implementing service learning in schools and colleges in Taiwan. Though many schools are promoting service learning curriculum to help students gain real life experience, most of the curriculum are not combined with learning. Instead, service-learning in Taiwan is a tool for students to contribute to the society or community by volunteering to help or work at local 
organizations such as hospitals, nursing homes or libraries. To investigate how servicelearning can affect students' learning and career development, service-learning should be integrated into academic courses to encourage students to explore their own potential and interest.

In terms of the research design, the date is limited to two categories focusing on the learning outcomes. Continuous and further research is needed to look into different aspects of students' developments.

\section{References}

Bringle, R.G., \& Hatcher, J.A. (1996). Implementing service learning in higher education. Journal of Higher Education, 67,221-223. https://doi.org/10.2307/2943981

Chiang, M., \& W. So. (2012). Effects of Fieldwork Experience on Empowering Prosepective Foreign Language Teachers. Teaching and Teacher Education 24(5), 1270-1287. https://doi.org/10.1016/j.tate.2007.05.004

Dewey, J. (1938). Experience and education. Kappa Delta Pi. New York: Touchstone.

Erickson, J.A., \& Anderson, J.B. (Eds.) (1997). Learning with the community: Concepts and models for service-learning in teacher education. Washington, DC: American Association Fro Higher Education.

Eyler, J.S., Giles, D.E., Jr., Stenson, C.M., \& Gray, C.J. (2001). At a glance: What we know about the effects of service-learning on college students, faculty, institutions and communities, 1993-2000: $3^{\text {rd }}$ Ed. Nashville, TN: Vanderbilt University.

Gray, M. J., Ondaatie, E., \& Fricker, R. (2000). Assessing service-learning: Resuslts from a survey of "Learn and serve America, higher education. Change, 32(2), 30-39. https://doi.org/10.1080/00091380009601721

Haneda, M. (2006). Classrooms as Communities of Practice: A Reevaluation. TESOL Quarterly 40(4), 807-817. https://doi.org/10.2307/40264309

Jacoby, B. (1996). Service-learning in higher education: Concepts and practices. San Francisco, CA: Jossey-Bass Publications.

LaMaster, K.J. (2001). Enhancing pre-service teachers' field experiences through the addition of an early field component. Journal of Experiential Education, 24(1), 27-33. https://doi.org/10.1177/105382590102400107

Reising, D., Allen, P., \& Hall, S.(2006). Student and community service through service learning: Part 1Student perceptions. Journal of Nursing Education, 45(12), 512-515.

Samaras, A. P., and S. Gismondi. (1998). Scaffolds in the field. Teaching and Teacher Education, 14(7), 715-733. https://doi.org/10.1016/S0742-051X(98)00024-9

Wenger, E. (1998). Communications of Practice. Cambridge: Cambridge University Press. https://doi.org/10.1017/CBO9780511803932

Zeichner, K. (1981). Reflective teaching and field-based experience in teacher education. Interchange, 12,1-22. https://doi.org/10.1007/BF01807805

Zeichner, K. M., \& Teitelbaum, K. (1982). Personalized and inquiry-oriented teacher education: An 
analysis of two approaches to the development of curriculum for field-based experiences. Journal of Education for Teaching, 8(2), 95-117. https://doi.org/10.1080/0260747820080201 